\title{
Biodegradation of Spilled Diesel Fuel in Agricultural Soil: Effect of Humates, Zeolite, and Bioaugmentation
}

\author{
Pavel Kuráň, ${ }^{1,2,3}$ Josef Trögl, ${ }^{2}$ Jana Nováková, ${ }^{1}$ Věra Pilařová, ${ }^{2}$ Petra Dáňová, ${ }^{2}$ \\ Jana Pavlorková, ${ }^{2}$ Josef Kozler, ${ }^{3}$ František Novák, ${ }^{4}$ and Jan Popelka ${ }^{2}$ \\ ${ }^{1}$ Research Institute of Inorganic Chemistry, a.s., Revoluční 84, 40001 Ústí nad Labem, Czech Republic \\ ${ }^{2}$ Jan Evangelista Purkyně University in Ústí nad Labem, Faculty of Environment, Králova Výšina 3132/7, \\ 40096 Ústí nad Labem, Czech Republic \\ ${ }^{3}$ MikroChem LKT, spol. s r.o. Přeseka 52, 37901 Třeboň, Czech Republic \\ ${ }^{4}$ Biological Centre AV ČR, v.v.i, Institute of Soil Biology, Na Sádkách 7, 37005 České Budějovice, Czech Republic
}

Correspondence should be addressed to Josef Trögl; josef.trogl@ujep.cz

Received 27 October 2013; Accepted 5 December 2013; Published 8 January 2014

Academic Editors: H. Hu and B. R. Wilson

Copyright (C) 2014 Pavel Kurán et al. This is an open access article distributed under the Creative Commons Attribution License, which permits unrestricted use, distribution, and reproduction in any medium, provided the original work is properly cited.

Possible enhancement of biodegradation of petroleum hydrocarbons in agricultural soil after tank truck accident ( 5000 mg/kg dry soil initial concentration) by bioaugmentation of diesel degrading Pseudomonas fluorescens strain and addition of abiotic additives (humates, zeolite) was studied in a 9-month pot experiment. The biodegradation process was followed by means of analytical parameters (hydrocarbon index expressed as content of $\mathrm{C}_{10}-\mathrm{C}_{40}$ aliphatic hydrocarbons, ratio pristane/ $\mathrm{C}_{17}$, and total organic carbon content) and characterization of soil microbial community (content of phospholipid fatty acids (PLFA) as an indicator of living microbial biomass, respiration, and dehydrogenase activity). The concentration of petroleum hydrocarbons $\left(\mathrm{C}_{10}-\mathrm{C}_{40}\right)$ was successfully reduced by $\sim 60 \%$ in all 15 experiment variants. The bioaugmentation resulted in faster hydrocarbon elimination. On the contrary, the addition of humates and zeolite caused only a negligible increase in the degradation rate. These factors, however, affected significantly the amount of PLFA. The humates caused significantly faster increase of the total PLFA suggesting improvement of the soil microenvironment. Zeolite caused significantly slower increase of the total PLFA; nevertheless it aided in homogenization of the soil. Comparison of microbial activities and total PLFA revealed that only a small fraction of autochthonous microbes took part in the biodegradation which confirms that bioaugmentation was the most important treatment.

\section{Introduction}

Aliphatic petroleum hydrocarbons are the most abundant environmental pollutants. However, due to their extreme nonpolarity with preferential binding to soil organic matter, their residual concentrations in soils are often high, despite fair biodegradability (as compared to other, more recalcitrant, organic pollutants) $[1,2]$. Bioremediation is considered to be a cost-effective and environmental-friendly approach for decontamination of polluted soils [3-5]. Nevertheless, the natural biodegradation in polluted soils is often slow due to factors such as high hydrocarbons concentrations, joint pollution with other pollutants (heavy metals), limiting nutrient content, insufficient water or oxygen supply, or low bioavailability of pollutants [5-7]. Developed bioremediation methods for organically polluted soils follow two main strategies, often combined together, that is, bioaugmentation (inoculation of soil with allochtonic, independently cultivated degrading microorganisms) and biostimulation (support of autochthonic (indigenous) degrading microorganism by abiotic additives) $[2,6]$. Biostimulation is carried out predominantly by improvement of the level of soil nutrients; nevertheless recent effort has been oriented into testing of other abiotic additives [7].

Humic substances were investigated previously as additives in bioremediation of polychlorinated biphenyls [8], aromatics [9-11], chlorinated aliphatics [12], and petroleum hydrocarbons [13]. Their clear role in bioremediation is not established yet, especially regarding generally less explored bioremediation of aliphatic hydrocarbons as compared to 
aromatic or halogenated pollutants. Humic substances possess many functional groups and have good sorption characteristics. Soils with higher humate content have higher retention capacity for water and nutrients, improved $\mathrm{pH}$ and redox buffering, or higher organic content, which all lead to improved soil fertility [14]. Both organic pollutants and heavy metals are well sorbed on humic substances $[10,14,15]$. From the bioremediation point of view this usually leads to immobilization and consequent decrease in pollutant toxicity $[11,12]$. On the other hand, humic substances can increase bioavailability of pollutants for degrading microorganisms [8], among other, by acting as surfactants $[9,11]$.

The role of zeolites in the biodegradation was studied much less. Overall zeolites are considered to improve soil quality by increasing retention capacity for water and nutrients. Zeolites and other porous inorganic materials can also bind microorganisms and thus serve as a good carrier for bioaugmentation $[12,16]$. Significant improvement of the biodegradation of pentachlorophenol was observed with humic substances bound on zeolite (the so-called organomineral complex) [12].

The aim of this study was to assess, in ex situ laboratory pot experiment, the effect of addition of humates and zeolite as well as bioaugmentation on the rate of biodegradation of spilled diesel $(\sim 5000 \mathrm{mg} / \mathrm{kg})$ in loamy agricultural soil after tank truck accident. The process was monitored via elimination of $\mathrm{C}_{10}-\mathrm{C}_{40}$ aliphatic hydrocarbons and total organic carbon (TOC) as required by European waste legislation (Council directive 1999/31/EC [17]). Soil microorganisms were monitored by determination of dehydrogenase activity and respiration, known to be indicative of proceeding biodegradation [13], and phospholipid fatty acid (PLFA) content, common method for estimation of living microbial biomass in soils $[18,19]$, sediments $[20]$, and other matrices [21].

\section{Materials and Methods}

2.1. Soil. A loamy agriculture soil (ash content 7\%, moisture $10 \%, \mathrm{pH} 7.5, \mathrm{~N}: \mathrm{P} \sim 6: 1$, and TOC $4.0 \%$ dry weight) was used. The soil was freshly polluted by diesel fuel (compliant with EN590 [22], temperate climatic zones) as a consequence of tank truck accident. The soil was removed from the site and $\sim 1000 \mathrm{~kg}$ was transported directly to laboratory. Significant portion of stones was eliminated by sieving through a $1 \mathrm{~cm}$ sieve.

2.2. Humates. Two types of humates from oxyhumolite (Duchcov, Czech Republic) and young brown coal (lignite, Mikulčice, Czech Republic [23]) were prepared by alkali extraction [24].

2.3. Zeolite. The zeolite of size $1.5-2 \mathrm{~mm}$ was purchased from Zeopol, a.s. (Brno, Czech republic), and added at concentration of $100 \mathrm{~g} / \mathrm{kg}$ wet soil.

2.4. Cultivation of Augmented Bacteria. Pseudomonas fluorescens diesel degrading strain from the culture collection of MikroChem LKT was cultivated one week in Bacterial
TABLE 1: Experiment variants.

\begin{tabular}{|c|c|}
\hline Variant & Composition \\
\hline I & Soil \\
\hline II & Soil + bacteria \\
\hline III & $\begin{array}{l}\text { Soil + bacteria + HS from lignite } \\
50 \mathrm{mg} / \mathrm{kg} \text { dry weight }\end{array}$ \\
\hline IV & $\begin{array}{l}\text { Soil + bacteria + HS from lignite } \\
150 \mathrm{mg} / \mathrm{kg} \text { dry weight }\end{array}$ \\
\hline $\mathrm{V}$ & $\begin{array}{l}\text { Soil + bacteria + HS from lignite } \\
450 \mathrm{mg} / \mathrm{kg} \text { dry weight }\end{array}$ \\
\hline VI & $\begin{array}{l}\text { Soil + bacteria }+ \text { HS from oxyhumolite } \\
50 \mathrm{mg} / \mathrm{kg} \text { dry weight }\end{array}$ \\
\hline VII & $\begin{array}{l}\text { Soil + bacteria + HS from oxyhumolite } \\
150 \mathrm{mg} / \mathrm{kg} \text { dry weight }\end{array}$ \\
\hline VIII & $\begin{array}{l}\text { Soil + bacteria + HS from oxyhumolite } \\
450 \mathrm{mg} / \mathrm{kg} \text { dry weight }\end{array}$ \\
\hline IX & $\begin{array}{l}\text { Soil + bacteria + zeolite + HS from lignite } \\
50 \mathrm{mg} / \mathrm{kg} \text { dry weight }\end{array}$ \\
\hline $\mathrm{X}$ & $\begin{array}{l}\text { Soil + bacteria + zeolite + HS from lignite } \\
150 \mathrm{mg} / \mathrm{kg} \text { dry weight }\end{array}$ \\
\hline XI & $\begin{array}{l}\text { Soil + bacteria + zeolite + HS from lignite } \\
450 \mathrm{mg} / \mathrm{kg} \text { dry weight }\end{array}$ \\
\hline XII & $\begin{array}{l}\text { Soil + bacteria + zeolite + HS from oxyhumolite } \\
50 \mathrm{mg} / \mathrm{kg} \text { dry weight }\end{array}$ \\
\hline XIII & $\begin{array}{l}\text { Soil + bacteria + zeolite + HS from oxyhumolite } \\
150 \mathrm{mg} / \mathrm{kg} \text { dry weight }\end{array}$ \\
\hline XIV & $\begin{array}{l}\text { Soil + bacteria + zeolite + HS from oxyhumolite } \\
450 \mathrm{mg} / \mathrm{kg} \text { dry weight }\end{array}$ \\
\hline $\mathrm{XV}$ & Soil + bacteria + zeolite \\
\hline
\end{tabular}

abbr.: HS: humate.

Salt Medium (BSM) [25] with diesel oil ( $1 \%)$ serving as a sole source of carbon and energy to an early exponential phase $\left(2.3 \times 10^{6} \pm 0.5 \times 10^{6} \mathrm{CFU} / \mathrm{mL}\right)$ and augmented in a concentration of $1.7 \pm 0.4 \times 10^{6} \mathrm{CFU} / \mathrm{g}$ wet soil once in the beginning of the experiment.

2.5. Experiment Variants. The experiment consisted of a total of 270 pots (conical pots, bottom diameter $135 \mathrm{~mm}$, upper diameter $180 \mathrm{~mm}$, and height $155 \mathrm{~mm}$ ) with conical underplate (bottom diameter $150 \mathrm{~mm}$, upper diameter $185 \mathrm{~mm}$, height $25 \mathrm{~mm}$ ) containing $2.5 \mathrm{~kg}$ of wet soil each: 15 variants of the experiment with different composition (Table 1) were prepared into 18 pots each (designed for six triplicate sampling).

Firstly, $2 \mathrm{~kg}$ of soil was weighted in $10 \mathrm{~L}$ plastic pail. For variant I $180 \mathrm{~mL}$ of water was added to soil and the mixture was rigorously stirred by a mixing device with special attachment allowing perfect homogenization of obtained mixture. For variant II $100 \mathrm{~mL}$ of bacterial suspension and $80 \mathrm{~mL}$ of water were added to the soil and the mixture was rigorously stirred. For variant XV $100 \mathrm{~mL}$ of bacterial suspension was mixed with $200 \mathrm{~g}$ of zeolite and $80 \mathrm{~mL}$ of water was added to the soil; the mixture was rigorously stirred.

For variants III-VIII $45 \mathrm{~g}$ of aqueous humate solution of required concentration was divided into three portions and 
subsequently added to soil, the mixture was rigorously stirred after addition of every portion of humate solution, $100 \mathrm{~mL}$ of bacterial suspension was added to obtained mixture, the rest of humate and bacterial suspension in beakers was washed with $35 \mathrm{~g}$ of water and combined with soil, and the mixture was again rigorously stirred.

For variants IX-XIV $45 \mathrm{~g}$ of aqueous humate solution of required concentration was divided into three portions and subsequently added to the soil, the mixture was rigorously stirred after addition of every portion of humate solution, $100 \mathrm{~mL}$ of bacterial suspension combined with $200 \mathrm{~g}$ of zeolite was added to the obtained mixture, the rest of humate and inoculate in beakers was washed with $35 \mathrm{~g}$ of water and combined with soil, and the mixture was again rigorously stirred.

The resulting mixture (soil with or without additives) was transferred from $10 \mathrm{~L}$ plastic pail to experimental pot and packed down by plastic spoon to prevent formation of the preferential channels in soil. Finally, the filled pots were transported to laboratory designed for pot experiments and covered with filter papers to slow down the water evaporation.

The soil moisture was maintained at $\sim 12-15 \%$ throughout the experiment. Two times a week the moisture measurement with a soil moisture-meter PCE-SMM1 (PCE GROUP, Meschede, Germany) and subsequent soil irrigating with distilled water were carried out.

2.6. Sampling. Samples were withdrawn at days $0,28,91,147$, 203, and 273 after the experiment startup. For each variant three entire pots were discarded. Aliquots for determination of soil moisture in particular pots were stored at ambient temperature maximally 3 days prior to determination. Aliquots for determination of dehydrogenase activity and respiration were stored under refrigerating conditions $\left(4^{\circ} \mathrm{C}\right)$ and determined one week after sampling. Aliquots for determination of PLFA were frozen $\left(-30^{\circ} \mathrm{C}\right)$ immediately and analyzed later.

All other determinations $\left(\mathrm{C}_{10}-\mathrm{C}_{40}, \mathrm{pH}\right.$, TOC, elemental composition, and $\mathrm{N}$ : $\mathrm{P}$ ratio) were carried out from dried soil, which was sieved through a $3.15 \mathrm{~mm}$ sieve for these purposes.

2.7. Analyses. Aliphatic hydrocarbon content expressed as the total concentration of $\mathrm{C}_{10}-\mathrm{C}_{40}$ was determined according to optimized method for soils and sludge [26]. Briefly, the soil was firstly extracted with acetone (p. a., Lach-Ner, Neratovice, Czech Republic); then the solution of hexane (95+ Pestapur, for pesticide residual analysis, Chromservis, Prague, Czech Republic) containing alkanes $\mathrm{C}_{10}$ and $\mathrm{C}_{40}$ was added and the soil was further extracted by stirring on magnetic stirrer. Finally, the extract was purified by florisil (60-100 mesh, LGC Promochem, Chromservis, Prague, Czech Republic). The content of $\mathrm{C}_{10}-\mathrm{C}_{40}$ in purified extract was determined by means of gas chromatograph HP 6890 series II coupled with flame ionization detector (GC-FID) on the column Equity-5, $30 \mathrm{~m} \times 0.25 \mathrm{~mm} \times 0.25 \mu \mathrm{m}$, with temperature program $50^{\circ} \mathrm{C}$, $2 \mathrm{~min}, 20^{\circ} \mathrm{C} / \mathrm{min}, 310^{\circ} \mathrm{C}, 18.5 \mathrm{~min}$. The detector temperature was $310^{\circ} \mathrm{C}$, and injector temperature was $300^{\circ} \mathrm{C}$. The injected volume was $1 \mu \mathrm{L}$ with splitless $0.2 \mathrm{~min}$. The linear velocity of nitrogen as carrier gas was $30 \mathrm{~cm} / \mathrm{s}$.
The ratios of pristane $/ \mathrm{C}_{17}$ and phytane/ $\mathrm{C}_{18}$ were determined from the chromatograms of $\mathrm{C}_{10}-\mathrm{C}_{40}$ determination on the basis of calibration curves for all four analytes.

The total organic carbon content (TOC) was determined according to ISO 14235 [27] used in agricultural laboratories of the Czech Republic.

Phospholipid fatty acids were analyzed by the adopted method of Zelles [18] using frozen soil samples. Briefly, the total soil lipids were extracted by a single-phase mixture of methanol, chloroform, and phosphate buffer (0.05 M, pH 7.4) in the ratio $2: 1: 0.8$. Lipids were fractionated into nonpolar lipids, glycolipids, and polar lipids on polar silica columns (Supelclean LC-Si, Sigma-Aldrich). Polar lipid fraction was subjected to mild alkaline methanolysis and prepared fatty acid methylesters were analyzed by means of GC-MS. Total PLFAs were quantified using methyl nonadecanoate internal standard [21].

Basal soil respiration (without substrate induction or moisture adjustment) was measured according to an adopted method [28-30] in $100 \mathrm{~mL}$ glass bottles ("pyrex") with $1 \mathrm{~g}$ of wet fresh soil. The evolved $\mathrm{CO}_{2}$ was captured in $0.5 \mathrm{M} \mathrm{NaOH}$ and determined by $\mathrm{HCl}(0.1 \mathrm{M})$ titration after $\mathrm{BaCl}_{2}$ addition. The activity was expressed in nmol of $\mathrm{CO}_{2}$ evolved per minute from $1 \mathrm{~g}$ of dry soil.

Dehydrogenase activity in soil was determined according to slightly modified standard method (ISO 23753-1 [31]). 2 g of fresh soil was incubated in $5 \mathrm{~mL}$ of solution of triphenyltetrazolium chloride (TTC, $1 \mathrm{~g} / \mathrm{L})$ in Tris buffer $(12.1 \mathrm{~g} / \mathrm{L}$, $\mathrm{pH} 7.6$ ) at $25^{\circ} \mathrm{C}$. Then, the produced triphenylformazan (TPF) was determined by means of spectrophotometry $(546 \mathrm{~nm})$ after acetone extraction. Absorbance of the background (obtained by incubation of $5 \mathrm{~g}$ in Tris buffer without TPF) was subtracted. The activity was expressed in $\mathrm{mU}$ per gram of dry soil (i.e., nmol of evolved TPF per minute per gram of dry soil).

2.8. Calculations and Statistics. Time course of $\mathrm{C}_{10}-\mathrm{C}_{40}$ elimination was fitted by zero-order kinetics (1) and first-order kinetics (2) using QCExpert statistical pack (Trilobyte software, Czech Republic):

$$
\begin{gathered}
c=c_{0}-k_{0} t, \\
c=c_{l}+\left(c_{0}-c_{l}\right) e^{-k_{1} t},
\end{gathered}
$$

where $c$ represents instantaneous concentration at time $t, c_{0}$ is initial concentration, $c_{l}$ is limit (asymptotical, "final") concentration, $t$ is time, and $k_{0}$ and $k_{1}$ are zero-order and first-order rate constants (regression parameters), respectively. Elimination half-lives were calculated as

$$
t_{1 / 2}=\frac{k_{1}}{\ln 2} \text {. }
$$

Mann-Whitney test and Bonferroni intervals were calculated using STATGRAPHICS Centurion XVI (StatPoint Technologies, USA), ANOVA, MANOVA, and Bonferroni tests for PFLA analysis using Statistica 10 (StatSoft, USA). All tests were evaluated at $\alpha=0.05$ significance level; all confidence intervals were calculated at 95\% confidence level. 


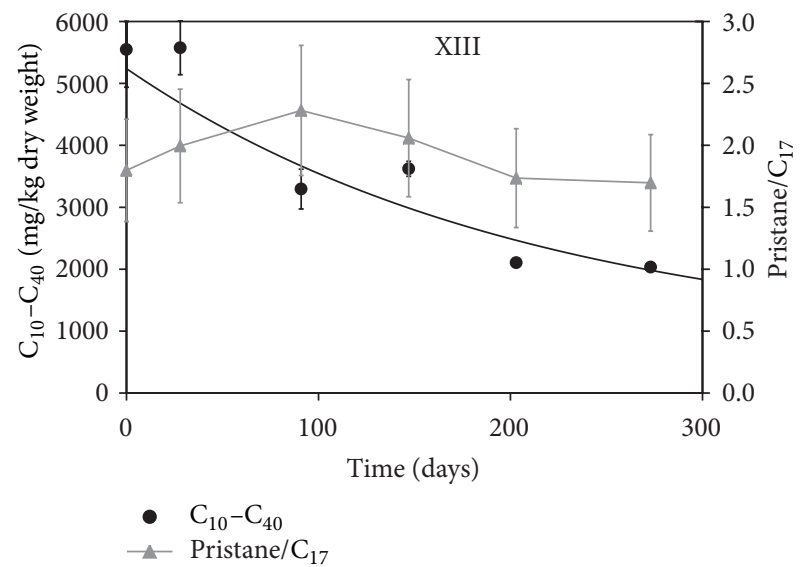

(a)

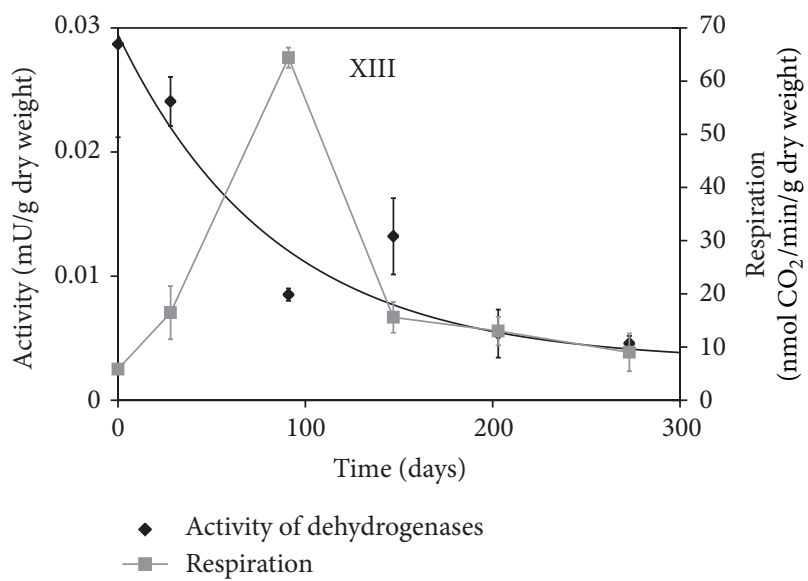

(b)

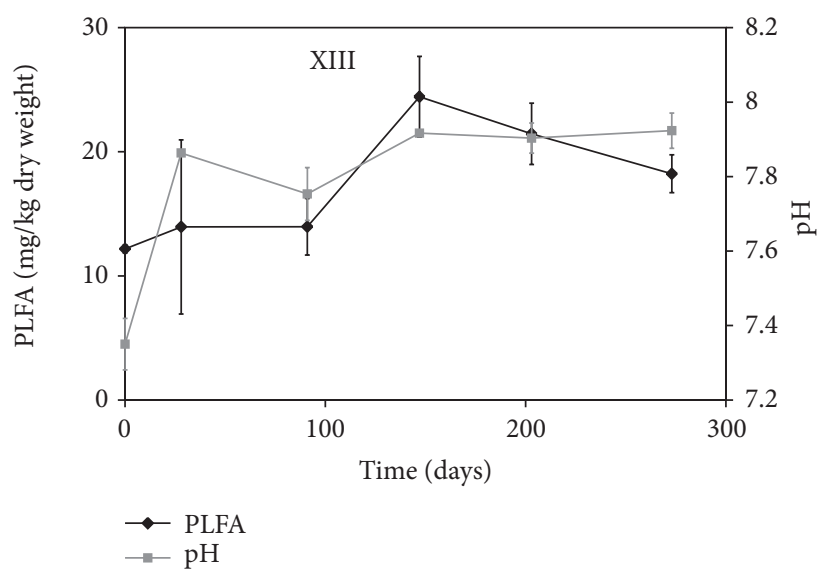

(c)

FIgURE 1: Typical time course of biodegradation process (variant XIII-bioaugmented soil with addition of zeolite and humate from oxyhumolite $150 \mathrm{mg} / \mathrm{kg}$ dry weight). Average values \pm standard deviation are plotted. (a) Concentration of $\mathrm{C}_{10}-\mathrm{C}_{40}$ and pristane/ $\mathrm{C}_{17}$ ratio $(\mathrm{b})$ Soil respiration and dehydrogenase activity. (c) Soil PLFA and pH.

\section{Results and Discussion}

3.1. Aliphatic Hydrocarbons Biodegradation. Typical course of $\mathrm{C}_{10}-\mathrm{C}_{40}$ biodegradation together with other important parameters is depicted in Figure 1 (individual charts for all variants are presented in Supplementary Material in Figure S1 (Supplementary Material available online at http://dx.doi .org/10.1155/2014/642427)).

Concentrations of $\mathrm{C}_{10}-\mathrm{C}_{40}$ aliphatic hydrocarbons decreased significantly from initial $5240 \pm 440$ to final $2330 \pm$ $270 \mathrm{mg} / \mathrm{kg}$ dry soil; both values were comparable (ANOVA) for all variants. In four variants (III, IV, V, XI, all with lignite addition) significant decrease of $\mathrm{C}_{10}-\mathrm{C}_{40}$ concentration was detected already at day 28; other variants exhibited at least a 28-day lag and significant decrease was first detected at day 91.

Slight preferential biodegradation of n-alkanes as compared to branched alkanes was confirmed by increase of the pristane $/ C_{17}$ ratio [32]. Due to data variability, the increase was significant for a few individual variants only; however it was significant overall; see Table S2 in Supplementary Material. Biodegradation of both pristane and linear $\mathrm{C}_{17}$ followed the first-order kinetics (in the later samples concentrations of these indicator compounds were very close to the limits of quantification), but biodegradation of pristane was somewhat delayed. A very similar pattern was determined also for phytane $/ \mathrm{C}_{18}$ ratio (not shown). Decrease of characteristic homologous series of paraffin (n-alkanes) sticking out from the envelope of nonseparated diesel oil complex mixture at the beginning of experiment in the whole range $\left(\mathrm{C}_{10}-\mathrm{C}_{40} \mathrm{n}\right.$ alkanes) could be read from chromatograms (see Figure S2 in Supplementary Material). These also show the preferential biodegradation of short-chained alkanes $\left(\mathrm{C}_{10}-\mathrm{C}_{25}\right)$ in comparison to higher nonpolar hydrocarbons. No shifts of retention time maxima were observed. This pattern was typical for all variants.

Half-lives of $\mathrm{C}_{10}-\mathrm{C}_{40}$ elimination are depicted in Figure 2. Compared to nonaugmented control (variant $\mathrm{I}$, the slowest biodegradation), the half-lives of $\mathrm{C}_{10}-\mathrm{C}_{40}$ elimination in other variants were significantly shorter. The shortest halflives were observed for the combination of all three factors (bioaugmentation + zeolite + humate $450 \mathrm{mg} / \mathrm{g}$, variants XI and XIV) and for combination of zeolite and bioaugmentation (variant XV). This suggests a positive effect of zeolite 
TABLE 2: Total phospholipid fatty acids (mg PLFA/kg dry soil, average values $\pm 95 \%$ Bonferroni intervals) as an effect of additives in bioaugmented variants (II to XV).

\begin{tabular}{|c|c|c|c|c|}
\hline $\begin{array}{l}\text { Time } \\
\text { (days) }\end{array}$ & $\begin{array}{l}\text { Zeolite } \\
\text { (XV) }\end{array}$ & $\begin{array}{l}\text { Humates + zeolite } \\
\text { (IX-XIV) }\end{array}$ & $\begin{array}{l}\text { Humates only } \\
\text { (III-VIII) }\end{array}$ & $\begin{array}{l}\text { No amendments } \\
\text { (II) }\end{array}$ \\
\hline 0 & $8.9 \pm 3.4^{\mathrm{abc}}$ & $12.7 \pm 1.6^{\mathrm{a}}$ & $13.6 \pm 2.3^{\mathrm{ab}}$ & $15.7 \pm 7.5^{\mathrm{abc}}$ \\
\hline 28 & $11.6 \pm 2.8^{\mathrm{abc}}$ & $12.4 \pm 1.7^{\mathrm{a}}$ & $16.1 \pm 2.4^{\mathrm{abcd}}$ & $15.0 \pm 13.0^{\mathrm{abcd}}$ \\
\hline 91 & $16.5 \pm 3.4^{\text {abcdef }}$ & $13.3 \pm 1.5^{\mathrm{a}}$ & $21.7 \pm 2.2^{\text {ef }}$ & $12.0 \pm 7.5^{\mathrm{abcde}}$ \\
\hline 147 & $16.3 \pm 2.8^{\mathrm{abcdef}}$ & $18.7 \pm 1.6^{\text {cde }}$ & $24.0 \pm 2.2^{\mathrm{f}}$ & $16.6 \pm 7.5^{\mathrm{abcde}}$ \\
\hline 203 & $21.1 \pm 2.8^{\text {abcdef }}$ & $21.1 \pm 1.7^{\mathrm{def}}$ & $22.6 \pm 2.0^{\mathrm{ef}}$ & $19.4 \pm 7.5^{\mathrm{abcdef}}$ \\
\hline 273 & $15.2 \pm 3.4^{\text {abcdef }}$ & $18.3 \pm 1.5^{\text {bcde }}$ & $20.7 \pm 2.0^{\mathrm{def}}$ & $22.7 \pm 13.0^{\mathrm{abcdef}}$ \\
\hline
\end{tabular}

Letters indicate homogenous groups of the values (Bonferroni test).

Bold-font rows indicate sampling times with significant differences in PLFA concentrations.

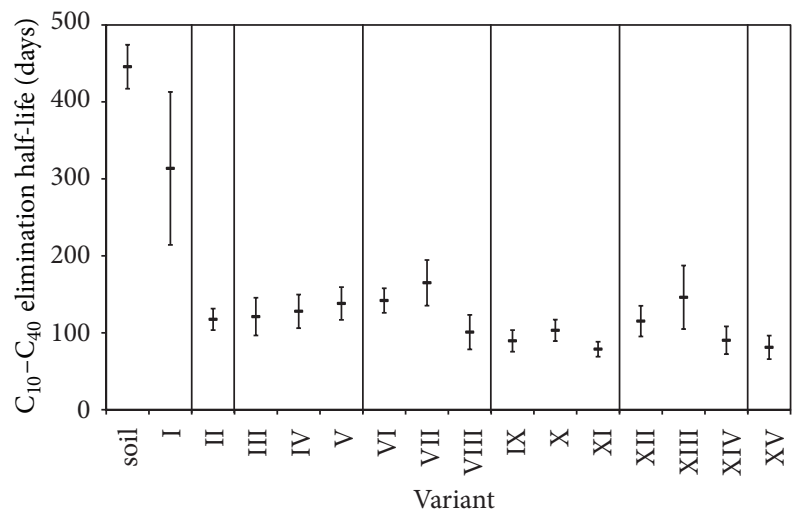

Figure 2: Comparison of half-lives of petroleum hydrocarbons $\left(\mathrm{C}_{10}-\mathrm{C}_{40}\right)$ decrease (average values $\pm 95 \%$-confidence) in all variants. The variant "soil" stands for stored soil from the locality without any treatment. $R$-squared ranged from 0.83 to 0.97 .

addition and a synergic effect of the treatments. Nevertheless this conclusion remains in the hypothesis level, since due to data variability even these shortest half-lives were mutually comparable to half-lives of other bioaugmented variants. All variants exhibited significantly shorter half-lives as compared to soil from the locality, which was not treated in any way. This result confirms the importance of irrigation and aeration during bioremediation of petroleum hydrocarbons $[2,6]$.

In accordance with the biodegradation progress TOC concentration decreased significantly in all variants from initial $3.8 \pm 0.2 \%$ to final $3.1 \pm 0.1 \%$ (details are presented in Supplementary Material as Table S1). Final TOC concentrations were comparable for all variants.

Soil $\mathrm{pH}$ increased significantly during the experiment period from initial 7.46 \pm 0.14 to final $7.98 \pm 0.09$ (Table S3 in Supplementary Material). Initial $\mathrm{pH}$ values were increased for variants with humates addition. Final $\mathrm{pH}$ values were significantly higher for augmented variants; other joint factors did not affect the final $\mathrm{pH}$ values.

3.2. Soil Microbial Communities during Biodegradation. The presence of microbial strains capable of degrading pollutants under given conditions is a prerequisite for successful bioremediation. Soil respiration exhibited a peak-type course [33] with initial respiration comparable to zero and maximum respiration at day 91 (Figure 1(b)) corresponding to maximum biodegradation of aliphatic hydrocarbons. Using MannWhitney test (used due to the absence of normal distribution of the respiration data) insignificant differences between individual variants were revealed; nevertheless, when evaluated jointly, the variants with humates without zeolite (III to VIII) exhibited significantly higher respiration than others. Dehydrogenase activities exhibited a first-order decrease in accordance with the decrease of hydrocarbons content (Figure 1(b)). The differences between variants were insignificant, but when evaluated jointly the variants with zeolite addition (IX to XV) exhibited significantly lower dehydrogenase activities compared to bioaugmented variants without zeolite (II to VIII).

The concentrations of soil PLFA in all variants increased during initial 147 days and then stagnated or slowly decreased (Figure 1(c)). Increase in the soil PLFA during the first half of the experiment indicates usual proliferation of soil microorganisms during biodegradation $[13,34,35]$ and it is in accordance with increasing respiration rate and hydrocarbon elimination. Evaluated individually, differences in PLFA concentrations between variants were insignificant. Considering humates (regardless of concentration and humate type) and zeolite as joint factors (Table 2), significant changes could be observed in the midcourse of the experiment (days 91 to 203). Addition of zeolites resulted in significantly lower PLFA concentrations while addition of humates resulted in significantly higher PLFA concentrations (MANOVA and Bonferroni test).

Absolute concentrations of PLFA in used polluted soil ( 8.9 to $24.0 \mathrm{mg} / \mathrm{kg}$ dry mass) are comparable to similar nonpolluted meadows or arable agricultural soils with intensive management [36]. On the other hand, the soil respiration (0 to $60 \mathrm{nmol} / \mathrm{min} / \mathrm{g}$ dry soil) is comparable rather to poorer soils such as younger phases of primary succession [30] or deep subsurface soil [28]. Decrease in microbial activity is even more pronounced if we count in the initial optimization of moisture content as well as higher temperature $\left(25^{\circ} \mathrm{C}\right)$ during respiration measurement as compared to more usual $20^{\circ} \mathrm{C}[28,30,37,38]$. This comparison suggests that the diesel spill affected negligibly the viability of soil microorganisms but it rather inhibited their metabolic activities, that is, it shifted them to an inactive state. 
3.3. Bioaugmentation Was the Most Significant Treatment. Bioremediation is a complex process with many potentially influencing factors, often unclear [33]. Deeper discussion of obtained data is therefore needed in order to draw conclusions. The $\mathrm{C}_{10}-\mathrm{C}_{40}$ data indicate low effect of addition of humates (variants III-VIII), zeolite (variant XV), or their combination (variants IX-XIV) on the rate of hydrocarbons biodegradation (biodegradation half-lives, Figure 2) upon bioaugmentation. Despite that the data indicate a possible positive effect of both additives, the increase in biodegradation rate was insignificant and obtained half-lives were comparable to variant II (bioaugmented soil only). On the contrary, the bioaugmentation of $P$. fluorescens degrading strain increased the biodegradation rate (significantly lower halflives of all bioaugmented variants II to XV as compared to nonaugmented variant I; Figure 2). This observation is even supported by comparison of kinetic models (zero-order versus first-order kinetics). Based on the calculation of Akaike criterion [39], for bioaugmented variants (II to XV) the $\mathrm{C}_{10^{-}}$ $\mathrm{C}_{40}$ concentration decrease was better explained by firstorder kinetics (2). On the contrary, the nonaugmented control (variant I) was better explained by the zero-order kinetics (1) indicating limitation by insufficient catalyst (i.e., degrading microorganisms). In accordance with the low microbial activity discussed in the previous section these data suggest insufficient number of degrading microorganisms in the original soil. Thus the bioaugmentation of degrading P. fluorescens strain was the most important treatment in the effort to increase the rate of biodegradation.

3.4. Effects of Humates and Zeolite on the Bioremediation Process. Opposite to expectation, no clear and significant effect of addition of humates or zeolite on the rate of biodegradation was found. Possible synergic effect of combination of humates and zeolite was indicated, but not significant. In addition, these additions had no effect on the terminal $\mathrm{C}_{10}-\mathrm{C}_{40}$ concentrations which were comparable in all variants. A few hypotheses can be formulated to explain why positive effects were not more distinct. First, our experiment integrated several established bioremediation techniques - that is, bioaugmentation of degrading strain and biostimulation by optimization of moisture content. Both techniques are known to be crucial for successful bioremediation [34] and could overwhelm the positive effects of humates and zeolite. Indeed, several studies demonstrated biostimulation to be a more important treatment than bioaugmentation [6, 13, 34]. Among others humic substances are considered to serve as surfactants [14] increasing pollutant bioavailability. The pollution in our case was fresh (i.e., more bioavailable [40]) which could blunt the positive effect of humates.

On the contrary a clear positive effect of humates on soil microbial community (increased PLFA, increased respiration rate) was observed in accordance with the study of Turgay et al. [13]. Viable and active soil microbial community is an important attribute of fertile and functional soil [14]. This is not, however, the case of polluted soils, where microbial communities are often disrupted [19] and which was also the case of our used soil. Microbial data suggested that despite the negligible effect on the biodegradation the addition of humates was not purposeless and it can contribute to the success of the bioremediation process by aiding in the restoration of microbial community.

In case of zeolite, it is likely that both augmented bacteria and indigenous soil bacteria were adsorbed on it [16] thus causing the observed decrease of PLFA and dehydrogenase activity. The temporal character of this decrease indicates that in longer-term scale also zeolite addition might be useful. At last it should be also noted that the presence of zeolite in the soil enabled simple visual monitoring of soil homogenization.

\section{Conclusion}

Successful biodegradation of fresh diesel fuel spill in loamy agricultural soil was achieved. While bioaugmentation was revealed to be the most important factor for increase of the biodegradation rate, the effect of humates and zeolite was only negligible. On the other hand the humates had positive effect on soil microbial community which may be of importance for restoration of soil function and fertility.

\section{Conflict of Interests}

The authors declare that there is no conflict of interests regarding the publication of this paper.

\section{Acknowledgments}

This work was funded by the Ministry of Industry and Trade of the Czech Republic (Grant no. FR-TI1/456) and Internal Grant Agency of J.E. Purkyně University. Authors wish to express their thanks to Jan Benda for the proof-reading and English correction.

\section{References}

[1] J. L. Stroud, G. I. Paton, and K. T. Semple, "Microbe-aliphatic hydrocarbon interactions in soil: implications for biodegradation and bioremediation," Journal of Applied Microbiology, vol. 102, no. 5, pp. 1239-1253, 2007.

[2] M. B. Yakubu, "Biological approach to oil spills remediation in the soil," African Journal of Biotechnology, vol. 6, no. 24, pp. 2735-2739, 2007.

[3] F. A. Caliman, B. M. Robu, C. Smaranda, V. L. Pavel, and M. Gavrilescu, "Soil and groundwater cleanup: benefits and limits of emerging technologies," Clean Technologies and Environmental Policy, vol. 13, no. 2, pp. 241-268, 2011.

[4] A. A. Juwarkar, S. K. Singh, and A. Mudhoo, "A comprehensive overview of elements in bioremediation," Reviews in Environmental Science and Biotechnology, vol. 9, no. 3, pp. 215-288, 2010.

[5] J. Pandey, A. Chauhan, and R. K. Jain, "Integrative approaches for assessing the ecological sustainability of in situ bioremediation," FEMS Microbiology Reviews, vol. 33, no. 2, pp. 324-375, 2009.

[6] M. Tyagi, M. M. R. da Fonseca, and C. C. C. R. de Carvalho, "Bioaugmentation and biostimulation strategies to improve 
the effectiveness of bioremediation processes," Biodegradation, vol. 22, no. 2, pp. 231-241, 2011.

[7] D. Sarkar, M. Ferguson, R. Datta, and S. Birnbaum, "Bioremediation of petroleum hydrocarbons in contaminated soils: comparison of biosolids addition, carbon supplementation, and monitored natural attenuation," Environmental Pollution, vol. 136, no. 1, pp. 187-195, 2005.

[8] F. Fava and A. Piccolo, "Effects of humic substances on the bioavailability and aerobic biodegradation of polychlorinated biphenyls in a model soil," Biotechnology and Bioengineering, vol. 77, no. 2, pp. 204-211, 2002.

[9] L. Ke, W. Bao, L. Chen, Y. S. Wong, and N. F. Y. Tam, "Effects of humic acid on solubility and biodegradation of polycyclic aromatic hydrocarbons in liquid media and mangrove sediment slurries," Chemosphere, vol. 76, no. 8, pp. 1102-1108, 2009.

[10] C. Plaza, B. Xing, J. M. Fernández, N. Senesi, and A. Polo, "Binding of polycyclic aromatic hydrocarbons by humic acids formed during composting," Environmental Pollution, vol. 157, no. 1, pp. 257-263, 2009.

[11] F. Fava, S. Berselli, P. Conte, A. Piccolo, and L. Marchetti, "Effects of humic substances and soya lecithin on the aerobic bioremediation of a soil historically contaminated by Polycyclic Aromatic Hydrocarbons (PAHs)," Biotechnology and Bioengineering, vol. 88, no. 2, pp. 214-223, 2004.

[12] K. Dercová, Z. Sejáková, M. Skokanová, G. Barančíková, and J. Makovníková, "Bioremediation of soil contaminated with pentachlorophenol (PCP) using humic acids bound on zeolite," Chemosphere, vol. 66, no. 5, pp. 783-790, 2007.

[13] O. C. Turgay, E. E. Erdogan, and A. Karaca, "Effect of humic deposit (leonardite) on degradation of semi-volatile and heavy hydrocarbons and soil quality in crude-oil-contaminated soil," Environmental Monitoring and Assessment, vol. 170, no. 1-4, pp. 45-58, 2010.

[14] M. Skokanová and K. Dercová, "Interactions of humic acids with contaminants," Chemicke Listy, vol. 102, no. 5, pp. 338-345, 2008.

[15] P. Janoš, A. Kopecká, and S. Hejda, "Utilization of waste humate product (iron humate) for the phosphorus removal from waters," Desalination, vol. 265, no. 1-3, pp. 88-92, 2011.

[16] Y. Liang, X. Zhang, D. Dai, and G. Li, "Porous biocarrierenhanced biodegradation of crude oil contaminated soil," International Biodeterioration and Biodegradation, vol. 63, no. 1, pp. 80-87, 2009.

[17] European union council directive 1999/31/EC on the landfill of waste, 1999.

[18] L. Zelles, Q. Y. Bai, R. Rackwitz, D. Chadwick, and F. Beese, "Determination of phospholipid- and lipopolysaccharidederived fatty acids as an estimate of microbial biomass and community structures in soils," Biology and Fertility of Soils, vol. 19, no. 2-3, pp. 115-123, 1995.

[19] A. Kaur, A. Chaudhary, A. Kaur, R. Choudhary, and R. Kaushik, "Phospholipid fatty acid: a bioindicator of environment monitoring and assessment in soil ecosystem," Current Science, vol. 89, no. 7, pp. 1103-1112, 2005.

[20] T. L. Kieft, E. Wilch, K. O’Connor, D. B. Ringelberg, and D. C. White, "Survival and phospholipid fatty acid profiles of surface and subsurface bacteria in natural sediment microcosms," Applied and Environmental Microbiology, vol. 63, no. 4, pp. 15311542, 1997.

[21] J. Trogl, I. Jirkova, P. Zemankova et al., "Estimation of the quantity of bacteria encapsulated in Lentikats Biocatalyst via phospholipid fatty acids content: a preliminary study," Folia Microbiologica, vol. 58, pp. 135-140, 2013.

[22] "Automotive fuels-Diesel-Requirements and test methods," European Committee For Standardization (CEN) EN 590, 2004.

[23] P. Janoš, L. Závodská, J. Lesný et al., "Young brown coals for environmental applications: composition, acid-base, ionexchange, and sorption properties of selected central European coals," in Coal Extraction, J. J. Stewart, Ed., pp. 71-90, Nova Science Publishers, New York, NY, USA, 2011.

[24] J. Novák, J. Kozler, P. Janoš, J. Čežíková, V. Tokarová, and L. Madronová, "Humic acids from coals of the North-Bohemian coal field I. Preparation and characterization," Reactive and Functional Polymers, vol. 47, no. 2, pp. 101-109, 2001.

[25] A. Čejková, J. Masák, and V. Jirků, “Use of mineral nutrients and surface-active substances in a biodegradation process modulation," Folia Microbiologica, vol. 42, no. 5, pp. 513-516, 1997.

[26] P. Kuráň, J. Nováková, and P. Janoš, "Determination of hydrocarbon index of $\mathrm{C}_{10}-\mathrm{C}_{40}$ in composts and sludges by GC-FID with traditional split/splitless injector," Chemicke Listy, vol. 105, no. 2, pp. 133-137, 2011.

[27] I. S. Organization, "Soil Quality: determination of organic carbon in soil by sulfochromic oxidation," ISO 14235, 1998.

[28] J. Frouz, T. Cajthaml, B. Kř́bek et al., "Deep, subsurface microflora after excavation respiration and biomass and its potential role in degradation of fossil organic matter," Folia Microbiologica, vol. 56, no. 5, pp. 389-396, 2011.

[29] J. Frouz, V. Krištůfek, M. Livečková, D. van Loo, P. Jacobs, and L. van Hoorebeke, "Microbial properties of soil aggregates created by earthworms and other factors: spherical and prismatic soil aggregates from unreclaimed post-mining sites," Folia Microbiologica, vol. 56, no. 1, pp. 36-43, 2011.

[30] M. Helingerová, J. Frouz, and H. Šantrůčková, "Microbial activity in reclaimed and unreclaimed post-mining sites near Sokolov (Czech Republic)," Ecological Engineering, vol. 36, no. 6, pp. 768-776, 2010.

[31] I. S. Organization, "Soil quality: determination of dehydrogenase activity in soils. Part 1: method using triphenyltetrazolium chloride (TTC),” ISO 23753-1, 2005.

[32] L. B. Christensen and T. H. Larsen, "Method for determining the age of diesel oil spills in the soil," Ground Water Monitoring and Remediation, vol. 13, no. 4, pp. 142-149, 1993.

[33] F. Benyahia, M. Abdulkarim, A. Zekri, O. Chaalal, and H. Hasanain, "Bioremediation of crude oil contaminated soils: A black art or an engineering challenge?" Process Safety and Environmental Protection, vol. 83, no. 4, pp. 364-370, 2005.

[34] E. Moliterni, L. Rodriguez, F. J. Fernández, and J. Villaseñor, "Feasibility of different bioremediation strategies for treatment of clayey and silty soils recently polluted with diesel hydrocarbons," Water, Air and Soil Pollution, vol. 223, pp. 2473-2482, 2012.

[35] E. Moliterni, R. G. Jimenez-Tusset, M. V. Rayo, L. Rodriguez, F. J. Fernandez, and J. Villasenor, "Kinetics of biodegradation of diesel fuel by enriched microbial consortia from polluted soils," International Journal of Environmental Science and Technology, vol. 9, pp. 749-758, 2012.

[36] V. L. Bailey, A. D. Peacock, J. L. Smith, and J. Bolton, "Relationships between soil microbial biomass determined by chloroform fumigation-extraction, substrate-induced respiration, and phospholipid fatty acid analysis," Soil Biology and Biochemistry, vol. 34, no. 9, pp. 1385-1389, 2002. 
[37] J. Frouz and A. Nováková, "Development of soil microbial properties in topsoil layer during spontaneous succession in heaps after brown coal mining in relation to humus microstructure development," Geoderma, vol. 129, no. 1-2, pp. 54-64, 2005.

[38] M. Holec and J. Frouz, "The effect of two ant species Lasius niger and Lasius flavus on soil properties in two contrasting habitats," European Journal of Soil Biology, vol. 42, supplement 1, pp. S213S217, 2006.

[39] H. Akaike, "New look at statistical-model identification," IEEE Transactions on Automatic Control, vol. AC-19, no. 6, pp. 716723, 1974.

[40] J. D. Stokes, G. I. Paton, and K. T. Semple, "Behaviour and assessment of bioavailability of organic contaminants in soil: relevance for risk assessment and remediation," Soil Use and Management, vol. 21, pp. 475-486, 2005. 

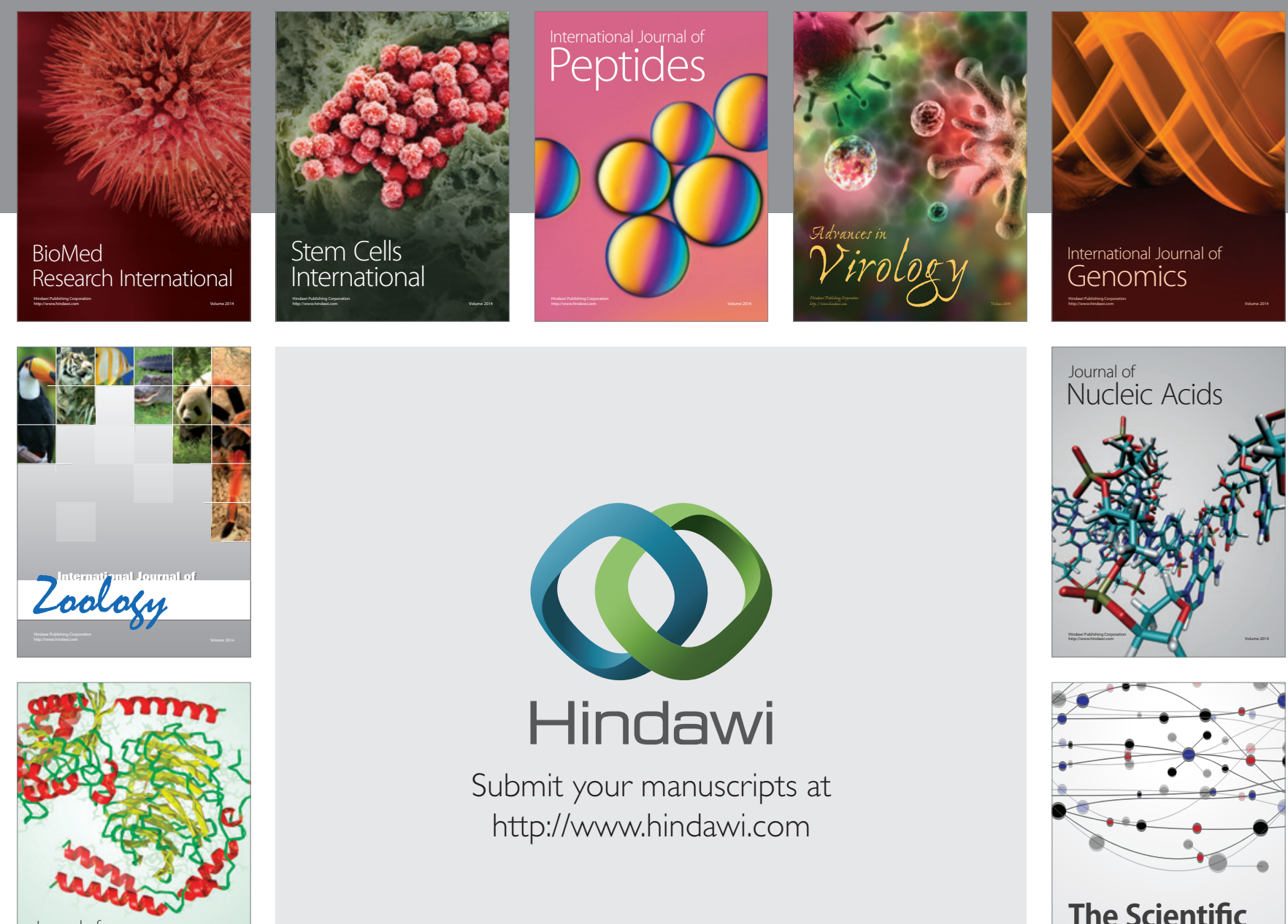

Submit your manuscripts at

http://www.hindawi.com

Journal of
Signal Transduction
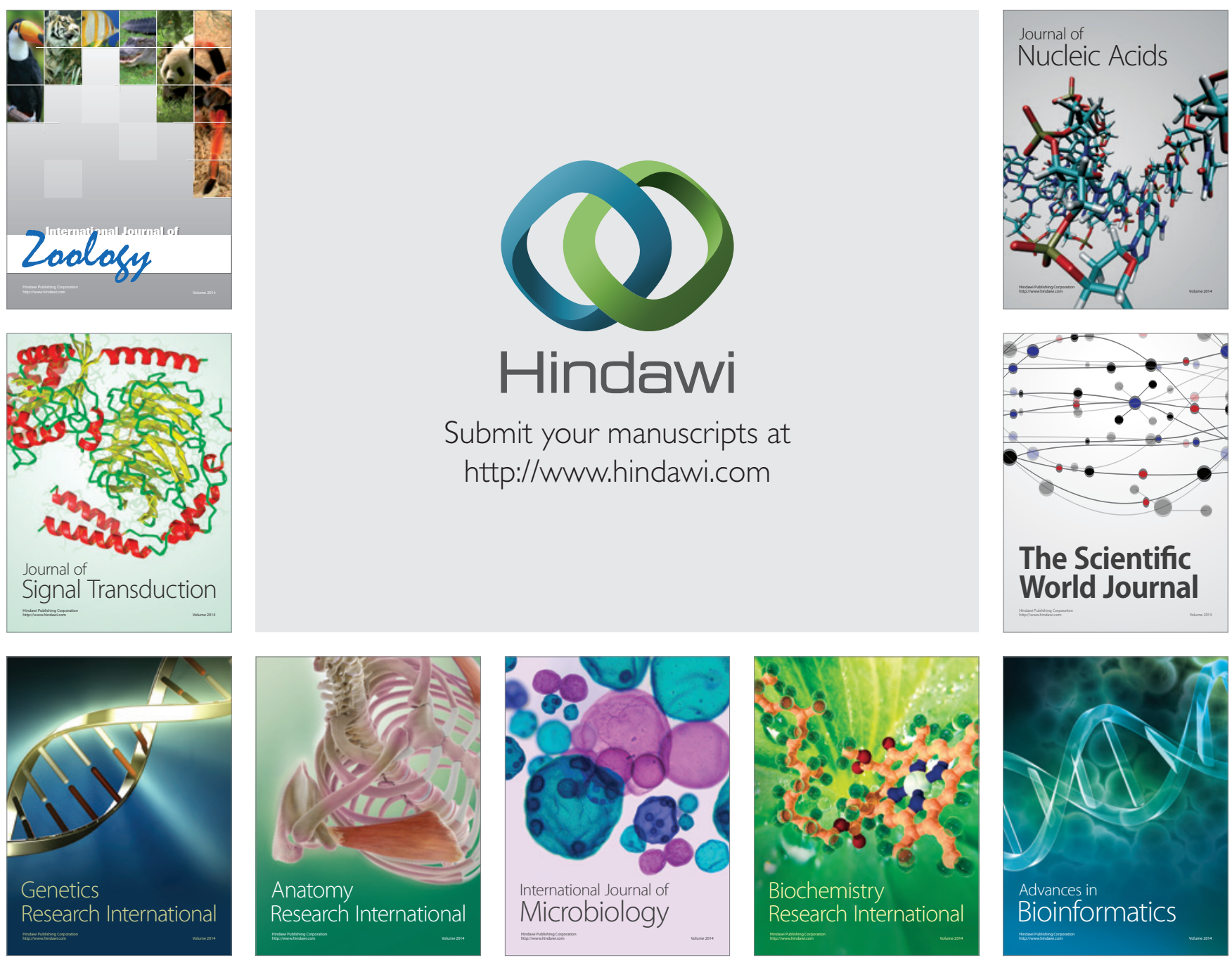

The Scientific World Journal
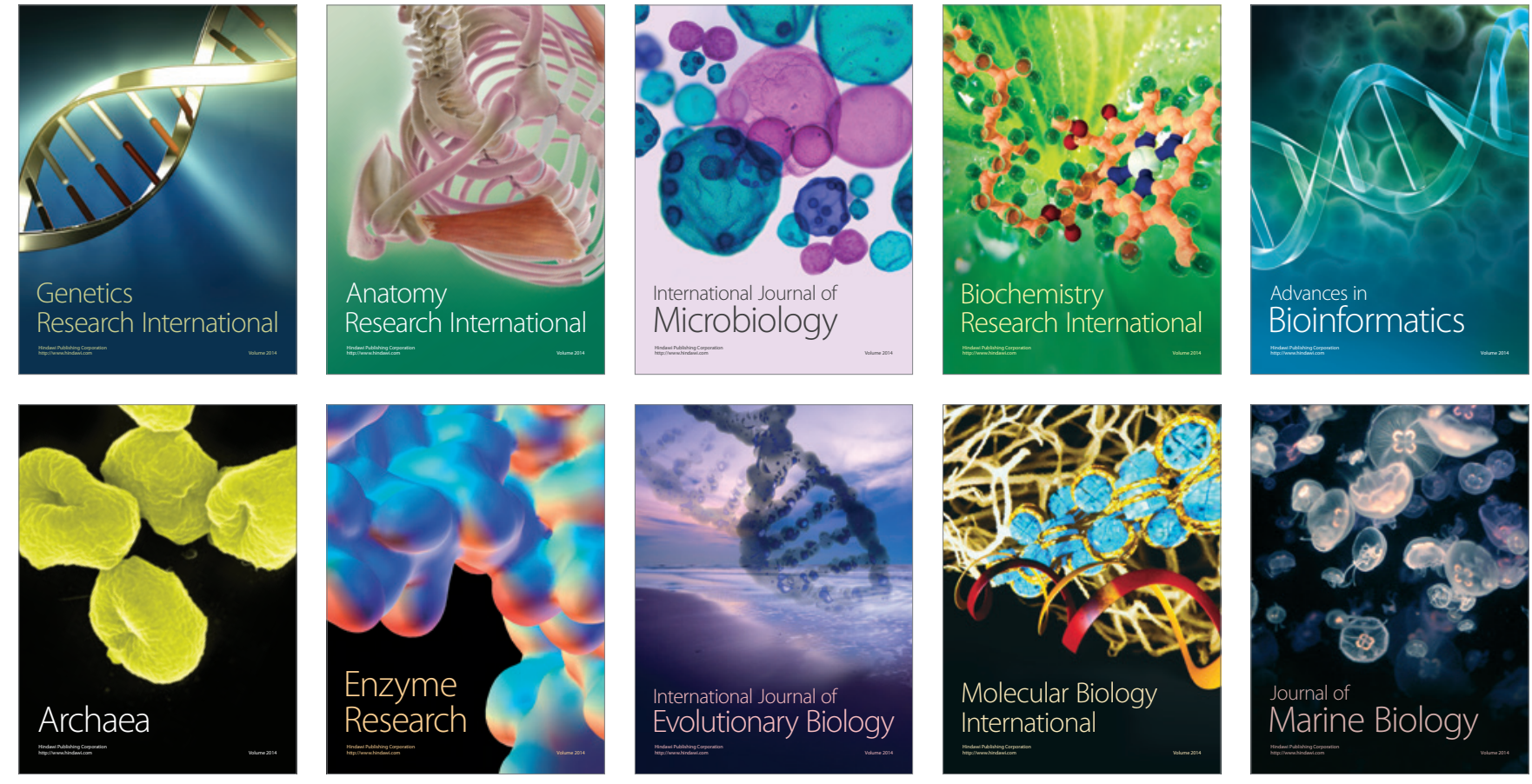